\title{
How to apply trade theory to the German unification? : Making sense of 'comparative advantage in nothing'
}

Citation for published version (APA):

Ziesemer, T. H. W. (1999). How to apply trade theory to the German unification? : Making sense of 'comparative advantage in nothing'. MERIT, Maastricht Economic Research Institute on Innovation and Technology. MERIT Research Memoranda No. 012 https://doi.org/10.26481/umamer.1999012

Document status and date:

Published: 01/01/1999

DOI:

10.26481/umamer.1999012

Document Version:

Publisher's PDF, also known as Version of record

\section{Please check the document version of this publication:}

- A submitted manuscript is the version of the article upon submission and before peer-review. There can be important differences between the submitted version and the official published version of record.

People interested in the research are advised to contact the author for the final version of the publication, or visit the DOI to the publisher's website.

- The final author version and the galley proof are versions of the publication after peer review.

- The final published version features the final layout of the paper including the volume, issue and page numbers.

Link to publication

\footnotetext{
General rights rights.

- You may freely distribute the URL identifying the publication in the public portal. please follow below link for the End User Agreement:

www.umlib.nl/taverne-license

Take down policy

If you believe that this document breaches copyright please contact us at:

repository@maastrichtuniversity.nl

providing details and we will investigate your claim.
}

Copyright and moral rights for the publications made accessible in the public portal are retained by the authors and/or other copyright owners and it is a condition of accessing publications that users recognise and abide by the legal requirements associated with these

- Users may download and print one copy of any publication from the public portal for the purpose of private study or research.

- You may not further distribute the material or use it for any profit-making activity or commercial gain

If the publication is distributed under the terms of Article $25 \mathrm{fa}$ of the Dutch Copyright Act, indicated by the "Taverne" license above, 


\section{HOW TO APPLY TRADE THEORY TO THE GERMAN UNIFICATION? Making sense of 'comparative advantage in nothing'}

Thomas Ziesemer, Maastricht University, MERIT and Department of Economics, P.O. Box 616, 6200 MD Maastricht, The Netherlands. E-MAIL: T.Ziesemer@algec.unimaas.nl. phone: 31-43-3883872.

\section{Introduction}

In their well-established textbook, Caves, Frankel and Jones (1993) (from here on abbreviated as CFJ), after explaining the basic trade model quote Lutz Hoffmann in order to show that there exist economists of eminent importance who fail to understand that a country cannot have 'comparative advantage in nothing'):

'Need every country have a comparative advantage in something? Yes, except for the accidental possibility of $\boldsymbol{a t i e}^{\boldsymbol{I}}$. Becoming relatively worse at some activity establishes that the country becomes relatively better at other activities. This is a point frequently misunderstood. For example, Lutz Hoffmann, president of the German Institute of Economic Research, in lamenting the recent rise in labour costs in eastern Germany, states that "East Germany is rapidly losing its comparative advantage as a low wage-economy and has no other advantage with which to compensate for this.” '(p.38)

Lutz Hoffmann taught trade theory for more than 10 years. He used the second edition of Caves and Jones, World Trade and Payments' for some time. He thinks about all policy problems he is concerned with in terms of carefully chosen frameworks. Thus it is fairly clear i) that one cannot reasonably suspect that he does not understand trade theory, and ii) that he certainly has something different in mind than the textbook authors CFJ.

Other textbook authors have been more cautious. Samuelson and Nordhaus (1989, p.910), for example, point out that the theory of comparative advantage has its limitations. Under involuntary unemployment or overvalued exchange rates an economy will be not on but rather inside its production possibility frontier "and the gains from trade along with the theory of comparative advantage would fail.“ “ These epochs of history are an apt reminder that the classical theory of comparative advantage retains its social relevance only when exchange rates, prices, and wages are at appropriate levels ... . “ 
Talking about the impact of wages in East-Germany, fixed at a level higher than those of full employment assumed in the simple basic trade model with its assumption of international labour immobility, seems to fit the class of problems indicated by Samuelson and Nordhaus (1989).

What we want to show in this paper is that an integration of these aspects into the frameworks of trade models may lead to a reduction of trade volumes, gains from trade and in this sense of comparative advantages and disadvantages. In the words of CFJ this means that the 'accidental possibility of a tie' under these circumstances may become a systematic possibility of a tie. Therefore is no longer accidental, and factors may move out of a country which is reducing production to its non-traded sector or stopping it altogether. Essentially this is what we see in weak regions.

In the following sections we give several variations of the Ricardian model and its Dornbusch/ Fischer/ Samuelson variant, the Heckscher-Ohlin model, and a model with nontraded goods. They all show - with one exception - that 'comparative advantage in nothing' can be a realistic description of high wage problems and weak infrastructure in East Germany and thus are anything but esoteric or false. ${ }^{2}$ What they have in common is that the violation of the assumptions of the basic trade models happens to occur in such a way that the export sector is damaged but the import-competing sector does not yet become an exporting sector. This leads to production of only the non-traded goods or, in simpler models, to total outward migration or $100 \%$ unemployment. To begin with, this need not be the case under unemployment from minimum wages because in this case a distorted production possibility curve PPC can be constructed and there may be perfect specialization. However, in the hypothetical case of unemployment of $100 \%$ or if all or some workers emigrate and/or if production is completely concentrated in the non-traded goods sector, there is comparative advantage in nothing or in leaving. We show below in several models that this occurs under wages fixed at too high a level in combination with migration.

\footnotetext{
${ }^{1}$ Italics and bold added by me, TZ.

2 Note that the statement of Lutz Hoffmann cannot be subsumed under the three classes of misunderstandings discussed in Krugman and Obstfeld (1997).
} 


\section{Theoretical cases of 'comparative advantage in nothing' in the Ricardian model}

What CFJ have in mind is that, for example in the Ricardian model, autarkic terms of trade, determining comparative advantage, are determined by the ratio of labour-input coefficients of one country relative to that of the other country, quite independent of the level of wages. Autarkic wages being the same for both sectors, if too high to achieve full employment, would raise both prices at zero profits and therefore have no impact on autarkic relative prices.

The only special case of no comparative advantage then would be that of identical slopes of PPC. Formally, this is a very special case because there are infinitely many other possible technologies leading to non-identical slopes of PPCs. Thus one might consider this to be an esoteric special case. Note, however, that Heckscher-Ohlin theory, favoured by a large sub-community within the community of trade economists, makes exactly that assumption and therefore one cannot a priori dismiss it as esoteric. However, we share the view that the assumption is not a good starting point.

The problem with CFJ is that they stop here, claiming that East Germany must have some comparative advantage. As a first logical step this is not wrong, but one should keep in mind that the derivation of a PPC is based on international labour immobility. However, by definition of the German Unification, labour is not internationally or regionally immobile. Thus one may not stop thinking without having thought through the migration process. The first step to be added is the following. Suppose, before migration, East Germany would have full-employment wages and so would the West of Germany. Then, with technologies in the East being less productive than in the West, the East must have lower wages than the West and has an incentive to migrate to the West. The new equilibrium then is one with all people in the West and no one in the East, or, briefly we would get 'Unification in the West'. This is what West Germany was afraid of. Therefore it is not an esoteric case either but it captures in a simple way what people feared. But with all people in the West and a zero population in the East, what is the comparative advantage of the East? Exactly nothing!

Because of this fear of migration to the West the idea was born to raise wages above full employment levels towards wages in the West. In the Ricardian model, with prices and wages at the level of the West but technologies less productive in the East compared to West (absolute disadvantage), firms in the East will anticipate negative profits and therefore will not produce at all. Unemployment is now at a rate of $100 \%$ due to the extreme simplifications made. With $100 \%$ unemployment what is the comparative advantage in the East? Again 
nothing! Of course this is all based of oversimplified models. But it still shows that we now have already three constructs of 'comparative advantage in nothing': the tie under identical technologies, $100 \%$ out-migration and $100 \%$ unemployment. This indicates that it should be possible to construct a realistic case.

Another Ricardian case can be constructed from the Dornbusch/Fischer/Samuelson (1977) model. In that model there is a continuum of goods rather than just two goods and this is the only difference with the Ricardian model. Relative labour-input coefficients for a good are defined by dividing one country's coefficient by that of the other country and they are ranked from low to high values. The home country will specialize in that range of goods in which it has relative labour-input coefficients $\mathrm{a} / \mathrm{a}^{*}<\mathrm{w}^{*} / \mathrm{w}\left(\mathrm{a}^{\prime} *\right.$ ‘ indicates the foreign country). If transport costs of the iceberg type are introduced in addition, each country will stop importing some of the goods in which the comparative advantage is small. This generates a non-traded goods sector. If transport costs are sufficiently large the size of the non-traded sector may go towards comprising the whole economy. Once again comparative advantage vanishes. In some parts of East Germany road infrastructure is so bad that trade is indeed unprofitable because of high transport costs. The case is obviously relevant although not associated with wage increases emphasized in the quote at the beginning of this paper.

\section{Comparative advantage and reduced gains from trade from fixed wages}

Admittedly, the assumptions of the previous cases are extreme. In this section we show that $\mathrm{CFJ}$ are perfectly right in the case of a minimum wage requirement in the $\mathrm{HO}$ model if the latter is unchanged otherwise. Consider the Heckscher-Ohlin model instead with just the one modification of fixed wages. Zero-profit conditions can then be written as equality of unit costs, $\mathrm{c}^{1}\left(\right.$.) and $\mathrm{c}^{2}$.), depending on factor prices for capital, r, and labour, $\underline{\mathrm{w}}$, and goods prices one of which can be used as numéraire:

$$
\mathrm{c}^{1}(\mathrm{r}, \underline{\mathrm{w}})=1 \text { and } \mathrm{c}^{2}(\mathrm{r}, \underline{\mathrm{w}})=\mathrm{p}
$$

In autarky, these are two equations to determine $r$ and $p$. If two countries are identical up to the level of wages the country with higher wages may have a comparative disadvantage in the labour-intensive sector. However, a relative labour abundance of East Germany will point to a (full employment) comparative advantage in the labour-intensive sector. From this we can 
clearly see what raising wages successively above their full-employment level does: From having labour-intensive goods as the export item of East Germany, raising wages makes them less and less competitive. Comparative advantage switches to capital-intensive goods, which are less sensitive to higher wages. Indeed there is no case of 'comparative advantage in nothing' in this case. This change in comparative advantage comes about not just by assuming identical technologies or deriving $100 \%$ migration or $100 \%$ unemployment as in the above cases but rather because wage increases, meant to keep people in the East, drive up relative costs to the extent that comparative advantage changes.

\section{FIGURE 1 OVER HERE}

To see more clearly that even the 'accidental possibility of a tie' is no exception here, consider the trade equilibrium with no migration and no capital movements for the case of a small country (see Figure 1). Assume prices are determined in the West and not affected by the East as at $\mathrm{P}^{\mathrm{F}}$ at the first best PPC. The second best PPC is well known ${ }^{3}$ to be TABT' or TA'B'T' or TA'B' 'T' for successively higher minimum wages. The two zero-profit conditions with fixed wages have only one variable to determine. The economy will be perfectly specialized if the wage is above full employment as at A'. But it will be imperfectly specialized if the minimum wage is below full-employment wages as at points A or A'. In case of perfect specialization the capital-market equilibrium condition will determine the quantity of the good produced. The labour-market equilibrium condition will determine labour demand. However, which good is produced depends on costs. Wages in excess of their fullemployment level outweigh the cost advantage of the labour-intensive good in the relatively labour-abundant East of Germany. As the fixed wage is a binding constraint the labourabundant country will export the capital-intensive good (see Figure 1) ${ }^{4}$. If the two forces are balanced (with $\mathrm{A}^{\prime}$ at $\mathrm{P}^{\mathrm{F}}$ ) it will produce both goods in accordance with the world market terms of trade (the tie) and import the capital-intensive good adjusting the MRS to the given world market terms of trade (see Figure when $\mathrm{A}^{\prime}$ approaches $\mathrm{P}^{\mathrm{F}}$ ). In other words, under autarky at this tie, households would have a MRS larger than the MRT and the autarkic prices, and therefore use trade even when there is a tie. There is indeed always a comparative advantage in this case, even at the tie, unless production and income vanish altogether when wages are so

\footnotetext{
${ }^{3}$ See Hazari 1978, Chap.6 or Bhagwati and Srinivasan 1983, Chap.22.

${ }^{4}$ Hazari 1978, Figures $6.4 \mathrm{a}$ and b, draws the case where the country has comparative advantage in the capital-intensive good under autarkic full employment conditions. Consequently there may be negative or positive gains from trade depending on the slope of the terms of trade line.
} 
high that zero production is optimal. This is not an interesting case. In short, CFJ are right in the case of a fixed wage in the HO model. One lesson from this model is that the comparative advantage idea need not be destroyed by unemployment considerations. The problem of East Germany from the point of view of this model could be seen in having negative gains from trade when specialization on capital-intensive goods leads to consumption at $\mathrm{C}^{\mathrm{F}}$ ".

\section{FIGURE 2 OVER HERE}

However, the kink in the PPC is a rather artificial construct. If one modifies the model to allow for natural resources like land with rental price $\rho$ in one of the sectors and an absolute advantage of the West, zero-profit conditions can be written as follows ${ }^{5}$ :

$$
\mathrm{c}^{1}(\mathrm{r}, \underline{\mathrm{w}} / \mathrm{A}, \rho)=1 \text { and } \mathrm{c}^{2}(\mathrm{r}, \underline{\mathrm{w}} / \mathrm{A})=\mathrm{p}
$$

Suppose in both sectors (abstracting from technological sources of comparative advantage) $\mathrm{A}=1$ for East Germany and A>1 for West Germany and otherwise technologies are identical across countries. With wages fixed and given the relative price $\mathrm{p}$ the second condition determines $r$ and the first then determines $\rho$. Higher $p$ implies higher $r$. A higher $r$ implies a lower $\rho$. Thus, higher $\mathrm{p}$ implies lower $\rho / \mathrm{r}$. This relation is drawn as the solid falling line in Figure 2. If productivity-adjusted wages are equal in the East and in the West, they have identical lines. As the West is assumed to be relatively capital-abundant it has a higher rent/interest ratio. The relative price of good 2 is lower in the West independent of the factor intensities of the sectors. The East therefore has comparative advantage in good $1\left(\mathrm{P}^{\mathrm{W}}<\mathrm{P}^{\mathrm{E}}\right)$. Suppose eastern wages are increased above western productivity-adjusted wages. To be profitable the second sector needs a lower interest rate $r$, for any given relative price, $\mathrm{p}$. With a higher real wage and a lower interest rate in the first equation, the first (second) effect dominates cost changes if the sector is labour-(capital-) intensive, thus requiring a decrease (increase) in the rent of land to fulfill the zero-profit condition. Assuming sector 1 is labourintensive it can be shown that $\rho$ goes down more than $r$, both for given $p$, and therefore the curve for the East shifts down (see the stippled line EE in figure 2). Autarkic prices between East and West Germany will be closer to each other. If eastern wages exceed productivityadjusted western wages far enough the comparative advantage of the East will be turned into a tie $\left(\mathrm{P}^{\mathrm{W}}=\mathrm{P}^{\mathrm{E}}\right)$ or even into a comparative advantage of capital-intensive goods $\left(\mathrm{P}^{\mathrm{W}}>\mathrm{P}^{\mathrm{E}}\right)$.

\footnotetext{
${ }^{5}$ We add an absolute technological advantage to the model of Batra and Beladi (1990).
} 
Clearly, the process of wage increases could stop at the tie, which is not accidental but rather stems from increased wages.

However, a model without factor movements is not suitable to analyze the German Unification, which by definition allows for migration and capital movements. With free factor movements, the above model may render sector 2 unprofitable if prices, interest and wages are determined in the West. Sector one could survive if land rents are low enough. However, if there is just one profitable sector it will comprise more than just a natural resource sector. Therefore we will replace it by a non-traded goods sector below.

\section{A model of a weak region with factor movements and specialization on non- traded goods because of fixed wages}

Suppose there are three sectors. All goods are produced with linearly homogeneous production functions that fulfill Inada conditions. In addition, the traded goods sectors have an upper limit of the capital-labour ratio at which they have a fixed labour productivity, but for simplicity it is assumed that the non-traded sector has no such limit or it is not binding. The most labour- intensive one is assumed to produce non-tradable goods and is not obliged to have the fixed wages, but the others are. Moreover, there are perfect capital movements at an interest rate fixed in the West, $\underline{\mathrm{R}}$, perfect migration rather than unemployment and prices for tradable goods are also fixed in the West, at $\mathrm{P}^{1}$ and $\mathrm{P}^{2}$. We assume that fixed wages of the traded goods sector are larger than flexible wages of the non-traded goods sector, $\underline{\mathrm{W}}>\mathrm{W}$. Zero-profit conditions (with the inequality indicating the possibility of no production in equilibrium) can now be written as

$\mathrm{C}^{1}(\underline{\mathrm{R}}, \underline{\mathrm{W}}) \geq \mathrm{P}^{1}$

$\mathrm{C}^{2}(\underline{\mathrm{R}}, \underline{\mathrm{W}}) \geq \mathrm{P}^{2}$

$\mathrm{CN}(\underline{\mathrm{R}}, \mathrm{W})=\mathrm{PN}$

Except for the price of non-traded goods, in all equations all factor and goods prices are given either from the west (nominal wages paid in the non-traded sector and fixed wages in the traded goods sector) or from the world market (prices of traded goods and the interest rates). If fixed wages and given interest rates are at appropriate levels, given prices of traded goods both traded goods sectors may produce. If they are higher they may make one sector 
unprofitable if substitution possibilities reach their limit. If they are still higher both tradable sectors may be unprofitable, again if the substitution possibilities of the other sector reach their limit. ${ }^{6}$

There are no exports of goods now if wages are fixed at too high a level and importcompeting goods are not produced. Both tradable goods are imported. With both traded goods not being produced there must be capital income from the West. ${ }^{7}$ The balance of payments in this case is

(BOP)

$$
R K^{e}=p^{1} C^{1}+p^{2} C^{2}
$$

With perfect specialization on non-traded goods production, $\mathrm{Y}$, the capital market equilibrium condition is

$$
\mathrm{K} / \mathrm{Y}[(\mathrm{W} / \mathrm{A}) / \mathrm{R}] \mathrm{Y}=\underline{\mathrm{K}}-\mathrm{K}^{\mathrm{e}}
$$

Capital demand on the LHS equals the endowment with capital, $\underline{\mathrm{K}}$, minus the capital export, $\mathrm{K}^{\mathrm{e}}$. The capital-input coefficient depends on relative factor prices because of the cost minimization. Capital movements are in the outward direction on net if fixed wages in the tradable goods sector are so high that it becomes unprofitable. The model allows for outward and inward migration, $\mathrm{L}^{\mathrm{m}}$. The labour-market equilibrium condition, with the pre-migration labour endowment $\underline{\mathrm{L}}$, is

$$
\mathrm{L} / \mathrm{Y}[(\mathrm{W} / \mathrm{A}) / \mathrm{R}] \mathrm{Y}=\underline{\mathrm{L}}-\mathrm{L}^{\mathrm{m}}
$$

Under the assumption that migrants do not send remittances in either direction but really move to that part of the country where they work, the budget constraint of households can be written as follows:

\footnotetext{
${ }^{6}$ Note that under Inada conditions and perfect factor movements the firms would have zero-profits at any given factor and goods prices because they could adjust the capital-labour ratio without limits. Perfect specialization then does not exist. This is the reason why we have to assume limited substitutability. To make this obvious, assume that the traded goods sectors have constant input coefficients. Given fixed prices and interest rates it is then obvious that at some wage level profits become negative and production stops.
} 


$$
p^{1} C^{1}+p^{2} C^{2}+p^{N} C^{N}=W\left(\underline{L}-L^{m}\right)+R \underline{K}
$$

Assuming the utility function $U=\left(C^{1}\right)^{\alpha}\left(C^{2}\right)^{\beta}\left(C^{N}\right)^{1-\alpha-\beta}$ we get expenditure for the three goods as

$\mathrm{p}^{1} \mathrm{C}^{1}=\alpha\left[\mathrm{W}\left(\underline{\mathrm{L}}-\mathrm{L}^{\mathrm{m}}\right)+\mathrm{R} \underline{\mathrm{K}}\right]$,

$\mathrm{p}^{2} \mathrm{C}^{2}=\beta\left[\mathrm{W}\left(\underline{\mathrm{L}}-\mathrm{L}^{\mathrm{m}}\right)+\mathrm{R} \underline{\mathrm{K}}\right]$,

$\mathrm{p}^{\mathrm{N}} \mathrm{C}^{\mathrm{N}}=(1-\alpha-\beta) \beta\left[\mathrm{W}\left(\underline{\mathrm{L}}-\mathrm{L}^{\mathrm{m}}\right)+\mathrm{R} \underline{\mathrm{K}}\right]$.

Using these shares the balance of payments (BOP) can be rewritten as

(BOP')

$$
R K^{\mathrm{e}}=(\alpha+\beta)\left[\mathrm{W}\left(\underline{\mathrm{L}}-\mathrm{L}^{\mathrm{m}}\right)+\mathrm{R} \underline{\mathrm{K}}\right]
$$

This equation is drawn in $\mathrm{K}^{\mathrm{e}}-\mathrm{L}^{\mathrm{m}}$ - space in Figure 3. Its negative slope is $-(\alpha+\beta) \mathrm{W} / \mathrm{R}$. Its positive vertical intercept is $(\alpha+\beta)[\mathrm{W} \underline{\mathrm{L}} / \mathrm{R}+\underline{\mathrm{K}}]$, the present value of all future imports as time goes to infinity using the nominal interest rate as the discount factor. Its economic interpretation is that the more capital is exported, the more goods can be imported and the less outward migration leads to the income under which these imports are demanded.

\section{FIGURE 3 OVER HERE}

Solving equations (K) and (L) for $\mathrm{Y}$ and equating them yields (after some manipulation) the factor-market-equilibrium condition drawn as upward sloping lines in Figure 3:

$$
\mathrm{K}^{\mathrm{e}}=\underline{\mathrm{L}}\{\underline{\mathrm{K}} / \underline{\mathrm{L}}-\mathrm{K} / \mathrm{L}[(\mathrm{W} / \mathrm{A}) / \mathrm{R}]\}+\mathrm{L}^{\mathrm{m}} \mathrm{K} / \mathrm{L}[(\mathrm{W} / \mathrm{A}) / \mathrm{R}]
$$

The cost-minimizing capital-labour ratio is the slope and the intercept is equal to the difference between the endowment ratio and the cost-minimizing ratio, which may be positive or negative. The economic interpretation of this curve, given the cost minimizing capitallabour ratio, is that more capital export means less capital employed, less output, less labour demand and therefore more labour emigration.

If the intercept of this curve is lower (higher) than that of the BOP curve there will be outward (inward) migration. Migration and capital export determined in Figure 3, we can conclude the capital and labour employment values from equations $(\mathrm{K})$ and $(\mathrm{L})$, and then the

\footnotetext{
${ }^{7}$ Intuitively speaking, Eastern households bring more capital to the West than western firms bring to the East. Note that this model is made only for the hypothetical situation of fixed wages that makes production of tradable goods unprofitable - the limiting case of the quote from which we started.
} 
value of output, $\mathrm{Y}$, and the income in the budget constraint (BC). Given the utility elasticities of consumption one gets the quantities consumed and the level of utility.

With no exports of goods and factor movements paying for imports there is again comparative advantage in nothing or only comparative advantage in leaving. The reason is that the whole economy may consist of the non-tradable sector only, because too high fixed wages have made the other sectors unprofitable and some eastern people may migrate into the West.

\section{Comparative static properties of the model}

To see the comparative static properties of the model a look at Figure 4 is instructive. It draws the curves (FE) and (BOP') in K-L space. Solving (BOP') for $\mathrm{K}=\underline{\mathrm{K}}-\mathrm{K}^{\mathrm{e}}$ as a function of $\mathrm{L}=$ $\underline{\mathrm{L}}-\mathrm{L}^{\mathrm{m}}$ yields a downward sloping line

$(B O P ') \quad \underline{K}-K^{\mathrm{e}}=(1 / \mathrm{R})\left[(1-\alpha-\beta) \mathrm{R} \underline{\mathrm{K}}-(\alpha+\beta)\left(\underline{\mathrm{L}}-\mathrm{L}^{\mathrm{m}}\right) \mathrm{W}\right]$

with vertical intercept $(1-\alpha-\beta) \underline{K}$ and horizontal intercept $(1-\alpha-\beta) R \underline{K} /[(\alpha+\beta) W]$. After elimination of $\mathrm{Y}$, equations $(\mathrm{K})$ and $(\mathrm{L})$ can be rewritten as

(FE')

$$
\underline{\mathrm{K}}-\mathrm{K}^{\mathrm{e}}=(\mathrm{K} / \mathrm{L})[(\mathrm{W} / \mathrm{A}) / \mathrm{R}]\left(\underline{\mathrm{L}}-\mathrm{L}^{\mathrm{m}}\right)
$$

This equation goes through the origin of Figure 4 and its slope is the cost-minimizing capitallabour ratio.

\section{FIGURE 4 OVER HERE}

An increase in the capital endowment, $\mathrm{d} \underline{\mathrm{K}}>0$, shifts the balance of payments equation outward and therefore increases $\mathrm{K}$ and $\mathrm{L}$ and lowers labour emigration, $\mathrm{dL}^{\mathrm{m}}<0$. The economic interpretation is that a higher capital endowment implies more interest income and more demand of all goods, also the non-traded ones. This increases demand for capital and labour. The latter removes emigration. Capital export increases to pay for increased imports (see BOP').

An increase in the labour endowment does not change any of the curves in K-L space, which means that capital and labour demand are unchanged and the additional labour moves out. As additional labour cannot change any factor price, the capital-labour ratio is unchanged. 
If labour demand was higher, there would also be an increase in capital demand and therefore capital export would be reduced. However, a look at (BOP') tells that this would bring the balance of payments out of balance unless labour emigrates by more than its endowment increases, which yields a contradiction in (BOP') because L would be decreased and K would be increased rather than leaving the $\mathrm{K} / \mathrm{L}$ ratio constant.

An increase in western wages, $\mathrm{d} \mathrm{W}>0$, moves the horizontal intercept of (BOP) to the left and rotates the (FE) line upward. Therefore labour demand is decreasing, $\mathrm{d} L<0$, and provokes outward migration, $\mathrm{d} \mathrm{L}^{\mathrm{m}}>0$.

An increase in interest rates, $\mathrm{d} \mathrm{R}>0$, rotates the $(\mathrm{FE})$ line downward and the BOP line gets a larger horizontal intercept, resulting in lower capital demand and more capital export.

Higher labour productivity leaves the BOP line unchanged, decreases the efficient wage and rotates (FE) downward. The capital-labour ratio decreases, capital demand decreases, capital export increases, labour demand increases, labour migrates back home.

\section{Conclusion}

We have derived several cases of comparative advantage in nothing, which can be relevant for East Germany.

The simplest case with little relevance is the $\mathrm{HO}$ assumption of identical technologies across regions implanted into the Ricardian model.

The second is the case with full employment wages leading to migration and unification in the West also within the Ricardian model.

The third case is with Western wage levels and prices in the East but lower productivity in all sectors, leading to negative profits and $100 \%$ unemployment also in the Ricardian model. Fourth, independent of wage rigidities, high transport costs stemming from insufficient infrastructure may lead to having a non-traded goods sector comprised of the whole economy.

Fifth, in a Heckscher-Ohlin model, augmented to have a factor land and an absolute technological advantage of the West, an excess of eastern wages over productivity-adjusted western wages can lead to a tie in which the East loses its comparative advantage in labourintensive goods.

Finally, modeling a non-traded sector and perfect capital movements under the assumption of the East being a small country on the goods, capital and labour markets, too 
high fixed wages in the sector of traded goods may lead to no exports of goods. All people are employed in the non-traded goods sector - if the latter is not bound to the fixed wages - or emigrate.

Thus there are many reasonable cases of 'comparative advantage in nothing' containing relevant problems of East Germany which Lutz Hoffmann might have had in mind when talking about the possible consequences of increasing wages. They appear either in the form of systematic rather than accidental ties with unemployment or in the form of production concentrated in the non-traded goods sector jointly with factor movements.

\section{References}

Batra, R.N. and H.Beladi (1990), Pattern of Trade between Underemployed Economies, Economica, 57, 485-93.

Bhagwati, J. and T.N. Srinivasan, Lectures on International Trade, MIT Press, New York, 1983.

Caves, R.E., J.A. Frankel and R.W. Jones, World Trade and Payments, $6^{\text {th }}$ edition, 1993.

Dornbusch,R., S.Fischer and P.A. Samuelson, Comparative Advantage, Trade and Payments in a Ricardian Model with a Continuum of Goods, American Economic Review, vol. 67, 1977, 823-831.

Hazari, B.R., The Pure Theory of International Trade and Distortions, Wiley, New York 1978.

Krugman, P. R., and M. Obstfeld, International Economics, 4th ed., 1997.

Samuelson, P.A. and W.D. Nordhaus, Economics, 13th ed., McGraw-Hill, New York etc. 1989. 


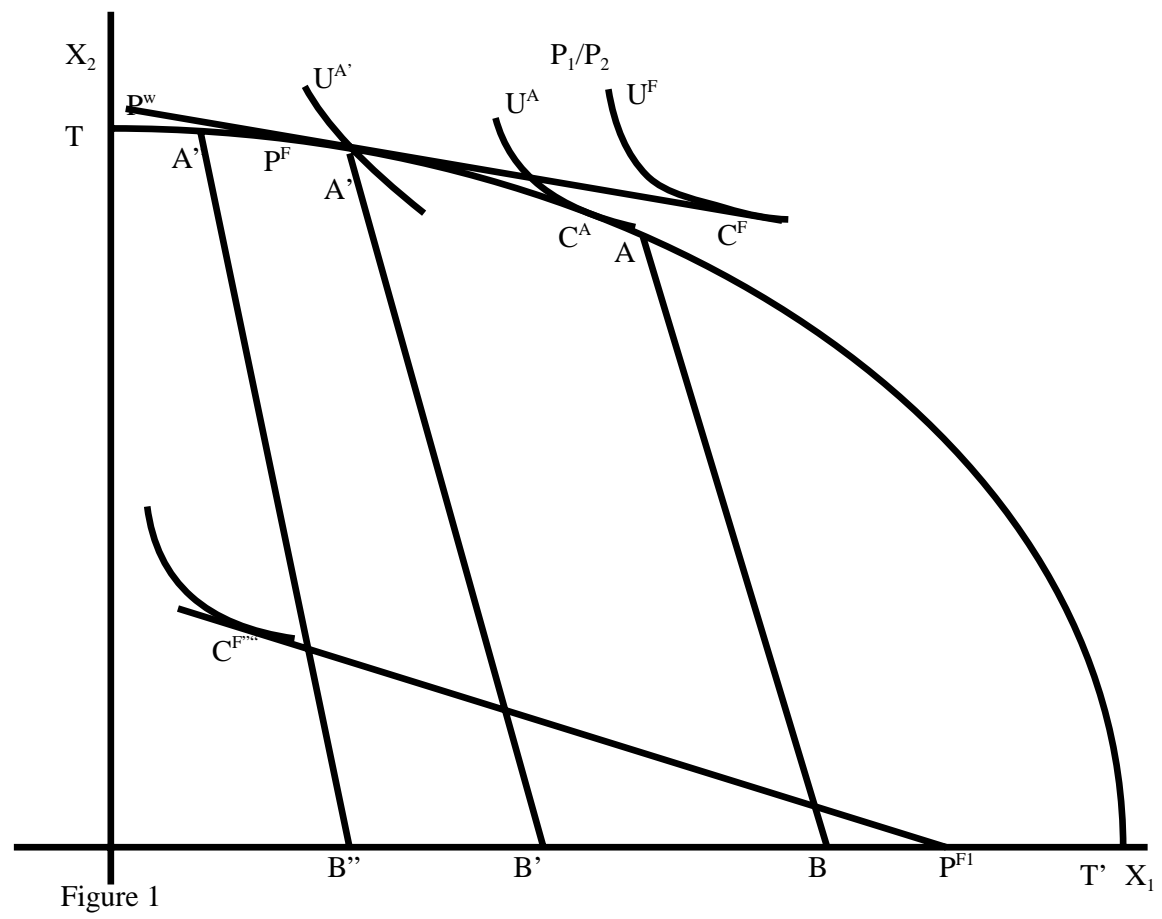




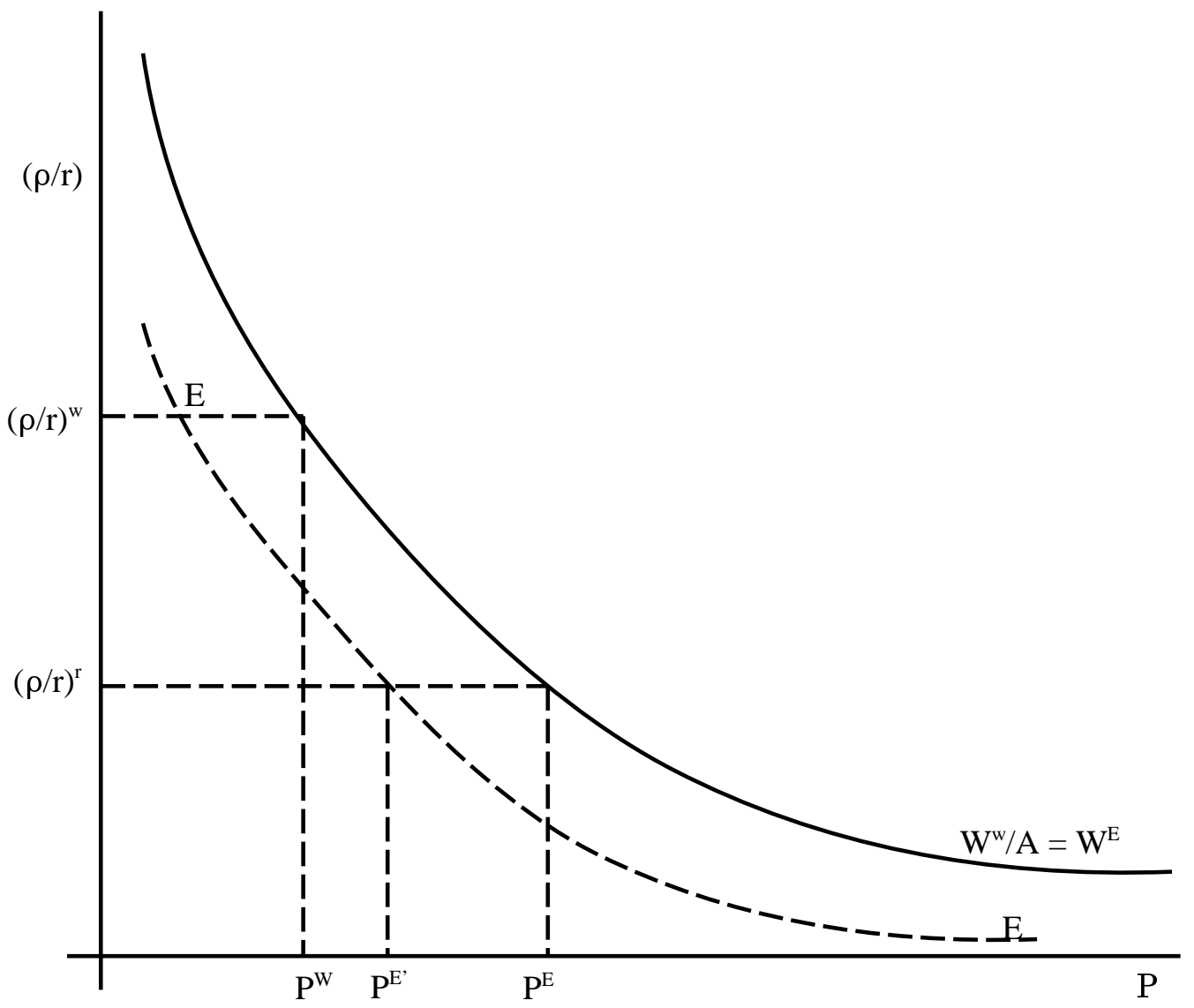

Figure2: Eastern wage increases working towards a tie 


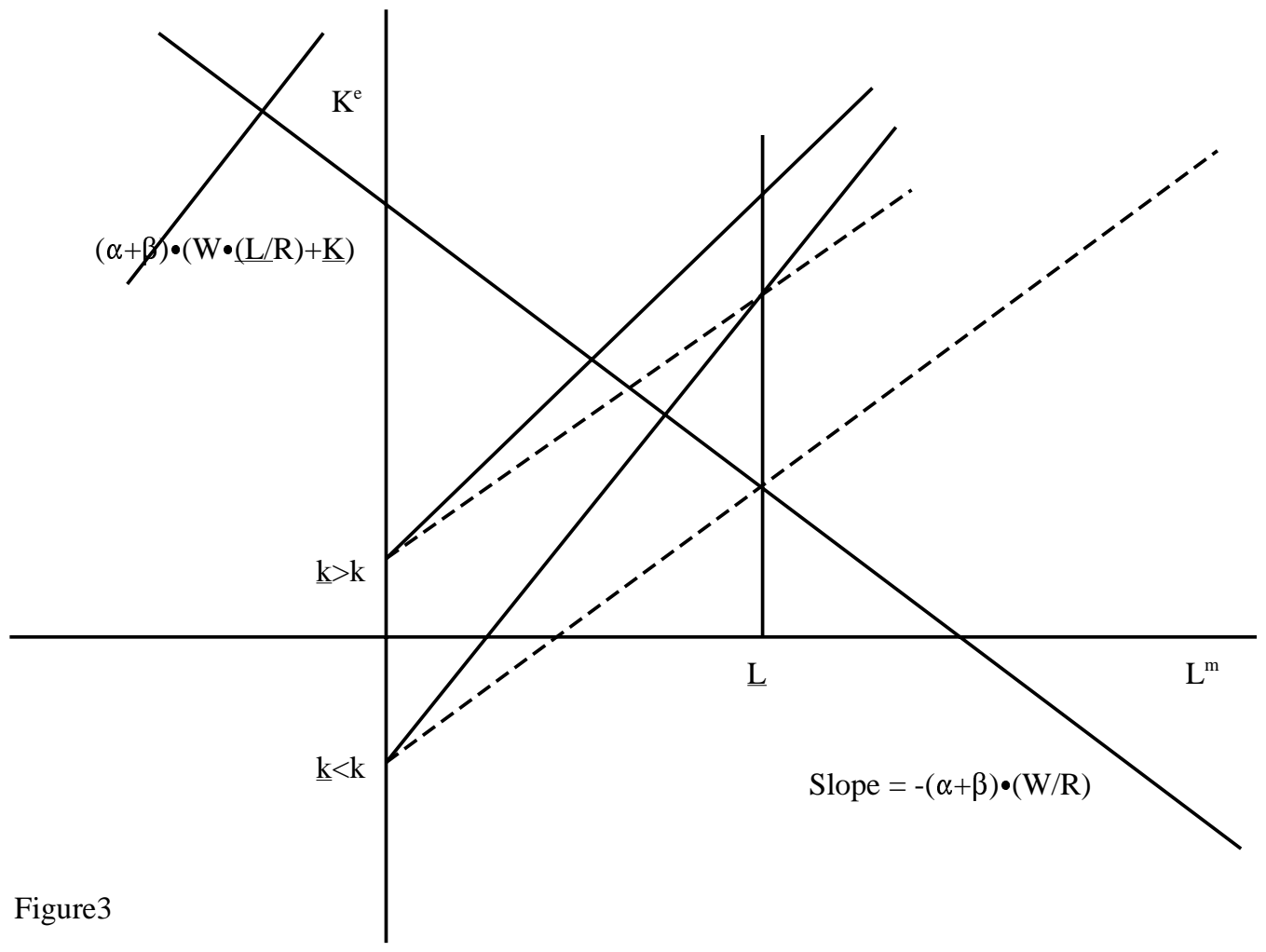




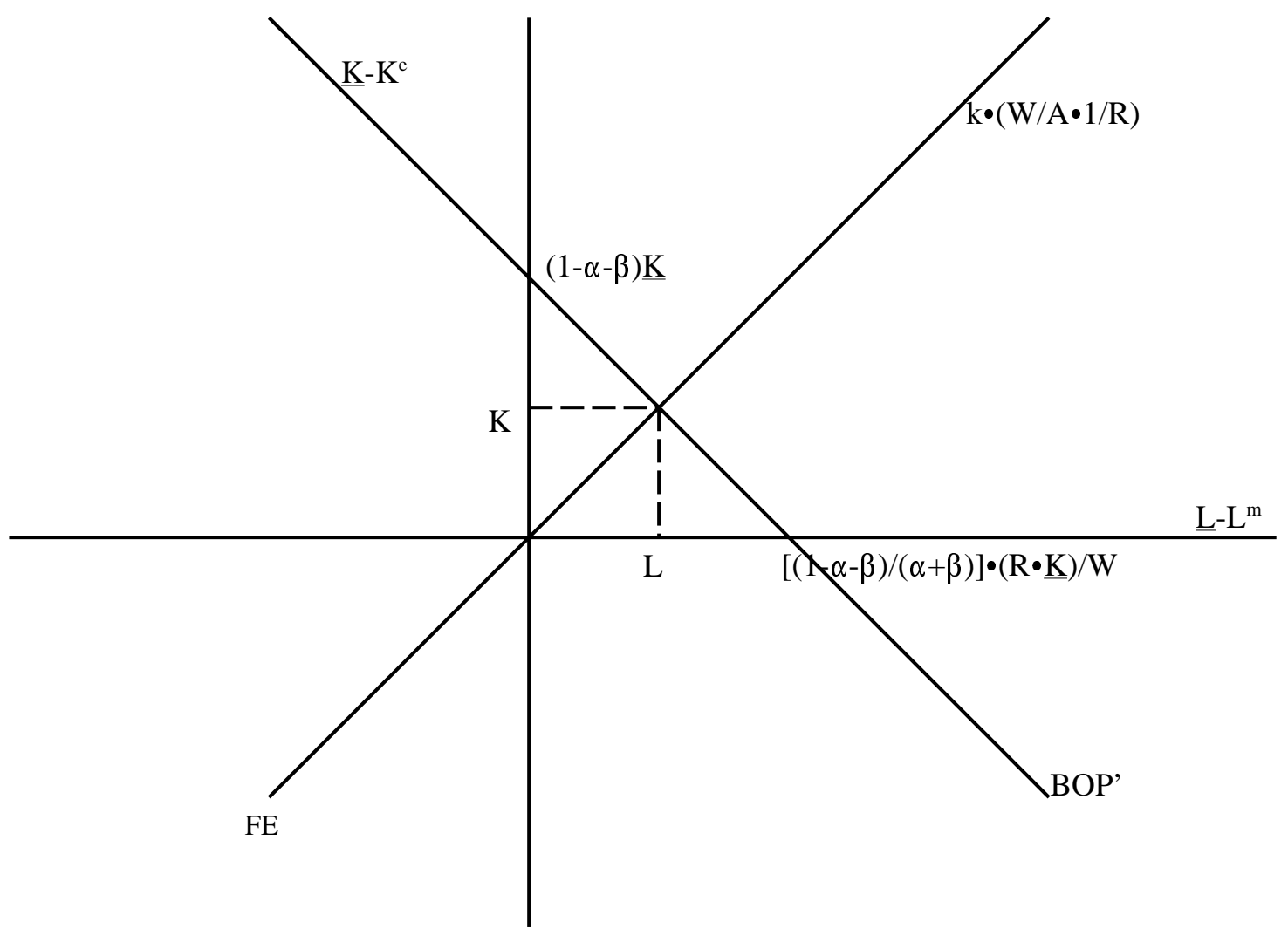

Figure4 